\title{
Reassessment of Seed Influence on Return Bloom and Fruit Growth in 'Bartlett' Pear
}

\author{
Steven A. Weinbaum ${ }^{1}$, Theodore M. DeJong, and John Maki \\ Department of Pomology, University of California, One Shields Avenue, \\ Davis, CA 95616
}

Additional index words. Malus $\times$ domestica, Pyrus communis, biennial bearing, parthenocarpy

\begin{abstract}
In a simple, yet elegant experiment conducted 30 years ago, Chan and Cain (1967) using 'Spencer Seedless', a facultatively parthenocarpic apple (Malus $\times$ domestica Borkh.) cultivar, proposed that seeds inhibited flowering and accentuated biennial bearing in apple. Their conclusions have been extrapolated widely to include apple and other species. We have tested the universality of their conclusions using 'Bartlett' pear (Pyrus communis $\mathbf{L}$.), a commercially important, facultatively parthenocarpic cultivar. Unlike 'Spencer Seedless' apples and seedless 'Bartlett' pear grown in France, California-grown seedless 'Bartlett' pear fruit strongly inhibited flowering the following year. However, the presence of seeds increased 'Bartlett' pear fruit size relative to seedless fruit by $13 \%$ and $20 \%$ in nonthinned and heavily-thinned pear trees, respectively, indicating that seeds increased fruit sink strength.
\end{abstract}

Chan and Cain (1967) addressed the role of apple seeds in floral initiation using one tree of a facultatively parthenocarpic apple cultivar, 'Spencer Seedless', growing at Geneva, N.Y. They concluded that seeds exert a primary role in the inhibition of flowering in apple. In recognition of the impact of this experiment in the world horticultural community, it was included among the "Classic Papers in Horticultural Science" (Proctor, 1989), and numerous authors (e.g., McArtney, 1994; Newell, 1991; Sprugel et al., 1991; Stanton et al., 1987; and Steffens et al., 1991) have cited Chan and Cain (1967) over the past 30 years as evidence for the inhibitory role of seeds in flowering. Without questioning the elegance of the original experiments (Chan and Cain, 1967), vegetative parthenocarpy is unusual in apple (Nyeki et al., 1998), and concerns may be raised with respect to the validity of extrapolation of their results and interpretation to other apple cultivars and species.

'Bartlett' pear is a commercially-important, facultatively parthenocarpic, self-sterile cultivar that sets fruit without pollination when grown in the Sacramento River Districts and Lake County of California. Elsewhere (in California and the rest of the world) it generally requires cross-pollination (Griggs and Iwakiri, 1954). Being facultatively parthenocarpic like 'Spencer Seedless' apple,

\footnotetext{
Received for publication 27 Jan. 2000. Accepted for publication 31 May 2000. We thank V.S. Polito for constructive comments on an early draft of the manuscript and F.G. Dennis, Jr. for thoughtful discussions and editorial refinement. The cost of publishing this paper was defrayed in part by the payment of page charges. Under postal regulations, this paper therefore must be hereby marked advertisement solely to indicate this fact.

${ }^{1}$ To whom requests for reprints should be addressed. E-mail address: saweinbaum@ucdavis.edu
}

'Bartlett' pear has also been studied to investigate the intra-spur relationship between seededness and subsequent flowering. In studies conducted in France, Huet (1972) reported that spurs supporting seedless fruit of 'Williams Bon Chretien' (Syn. 'Bartlett') were more likely to flower in the subsequent year than were spurs in which seeded fruit were present. In contrast, neither seedless nor seeded fruit of 'Bartlett' pear were particularly inhibitory to floral initiation when studied in California (Griggs et al., 1970). Given the contradictory results of Huet (1972) and Griggs et al. (1970), our objectives were to: 1) reassess the relationship between seededness and flowering in 'Bartlett' pear; and 2) quantify the effect of seededness on fruit size when resource availability is varied as a result of manipulating crop load.

\section{Materials and Methods}

Expt. 1.A. Effect of seededness on return bloom: Tagged spurs, full crop load. On 19 Mar. 1992, 12 mature, cropping 'Bartlett' pear trees, were selected for uniformity within a single orchard row in Kelseyville, Calif. (lat. $39^{\circ} \mathrm{N}$, long. $\left.123^{\circ} \mathrm{W}\right)$. Two treatments $(6$ replicate trees per treatment), "pollinated" and "nonpollinated' were randomized within a section of the orchard row. Thirty-five spurs per tree were selected from throughout the tree canopies and tagged before bloom. Six trees were randomly designated 'pollinated trees'. When the flowers on the tagged spurs trees reached full bloom (27 Mar.), they were manually pollinated, using glass rods, with pollen obtained from the Pyrus communis cv Winter Nelis to ensure development of seeded fruit. The flowers on tagged spurs on the remaining six trees set fruit without handpollination. Spurious pollination of "nonpollinated" trees was unlikely because there were no pollinizers in the orchard. In late July, all fruit from tagged spurs were harvested, labeled with their respective spur number and weighed to the nearest gram. Fruit were sliced transversely, and seeds were counted to document parthenocarpic vs. seeded fruit set. A total of 375 of the 420 tagged spurs persisted over the winter, and the effect of seededness on the percentage of return bloom was determined in the last week of Mar. 1993.

Expt. 1.B. Effect of seededness on return bloom: Light crop load. On the same day (19 Mar. 1992) an additional eight trees (four replicate trees per treatment) were selected from a section of the same row using the same criteria (uniform size, vigor, previous season yield), and 30 spurs per tree were selected and tagged. At full bloom (27 Mar. 1992), trees were randomly assigned to one of two treatments. All flowers on tagged spurs on four of the trees were hand-pollinated as described above using 'Winter Nelis' pollen; the flowers on tagged spurs on the remaining four trees set fruit parthenocarpically. All nontagged flower clusters were removed, and tagged spurs were thinned to one fruit per spur on 26 May to ensure that fruit growth was not resourcelimited (Grossman and DeJong, 1995). Fruit were harvested at the end of July to determine fruit weight, fruit diameter, and seed number per fruit.

Expt. 2. Effect of parthenocarpic crop load on return bloom, fruit number, fruit weight and yield in the subsequent year. In 1993, the total number of flower clusters per tree were counted on 16 trees representing four treatments from the previous year; nonpollinated (parthenocarpic)-nonthinned and pollinated (seeded)-nonthinned, from Expt. 1.A and nonpollinated (parthenocarpic)-thinned and pollinated (seeded)-thinned from Expt. 1.B. Only four of the six trees per treatment in Expt. 1.A were used in Expt. 2. Fruit on all 16 trees set parthenocarpically in 1993. At harvest, both the number and weight of fruit per tree were recorded.

Statistical analysis. Data were analyzed using analysis of variance procedures of SAS software, version 6.10 .

\section{Results}

Expt. 1.A. Effect of seededness on return bloom: Tagged spurs, full crop load. Manual pollination of 'Bartlett' pearflowers with 'Winter Nelis' pollen significantly increased fruit number per spur, fruit weight, fruit weight per spur and seed number per fruit (Table 1). Seeded fruits averaged $>12 \%$ heavier than seedless fruit, and pollinated spurs carried $\approx 25 \%$ greater fruit weight than did spurs carrying seedless fruit. Fruit from pollinated flowers contained more than seven seeds per fruit, whereas those from nonpollinated flowers were seedless, as expected (Table 1).

Eight percent of the tagged spurs bearing seedless fruit in 1992 flowered again in 1993 vs. $<1 \%$ of the spurs bearing seeded fruit (Table 1). Thus, although return bloom was higher on spurs bearing seedless vs. seeded fruit, the percentage of return bloom on spurs 
Table 1. Effect of pollination on seed number, fruit retention and fruit weight in 'Bartlett' pear in 1992 and on return bloom in 1993. (Expt. 1.A, full crop load).

\begin{tabular}{|c|c|c|c|c|c|c|c|c|}
\hline \multirow[b]{3}{*}{ Treatment } & \multirow{3}{*}{$\begin{array}{l}\text { No. of } \\
\text { spurs } \\
\text { tagged }\end{array}$} & \multicolumn{3}{|c|}{1992} & \multirow{3}{*}{$\begin{array}{l}\text { Seeds } \\
\text { per fruit }\end{array}$} & \multicolumn{3}{|c|}{1993} \\
\hline & & \multirow{2}{*}{$\begin{array}{c}\text { Fruit } \\
\text { per spur }\end{array}$} & \multicolumn{2}{|c|}{ Fruit wt } & & \multicolumn{2}{|c|}{ No. of spurs } & \multirow{2}{*}{$\begin{array}{c}\text { Spurs } \\
\text { flowering }(\%)^{\mathrm{y}}\end{array}$} \\
\hline & & & (g/fruit) & (g/spur) & & Persisting & Flowering & \\
\hline Pollinated & 210 & 1.7 & 176 & 301 & 7.3 & 188 & 1 & 0.53 \\
\hline Nonpollinated & 210 & $1.5^{*}$ & $156^{* * *}$ & $24^{* *}$ & $0.0^{* *}$ & 187 & 15 & 8.02 \\
\hline
\end{tabular}

${ }^{\mathrm{z}}$ Each datum represents the mean for six trees.

yercentage spurs flowering was calculated by dividing the number of spurs flowering by the number of persisting spurs.

${ }^{*}, *$ Significantly different from pollinated at $P \leq 0.05$ or 0.01 .

bearing seedless fruit was an order of magnitude lower than that reported for 'Spencer Seedless' apple (Chan and Cain, 1967). The inverse relationship between crop load of seedless fruit in 1992 and the number of flower clusters per tree in 1993 indicated that, unlike 'Spencer Seedless' apple, even seedless fruit of 'Bartlett' pear inhibited return bloom.

Expts. 1.B. and 2. Effects of seededness and crop load on return bloom, fruit number, fruit weight and yield in the subsequent year. Trees thinned to 30 seedless fruit in 1992 produced $44 \%$ more flower clusters per tree than did nonthinned trees that carried a normal crop of seedless fruit (Table 2). Unlike flowering, yield and fruit growth were independent of the previous year's crop load and differences in the level of return bloom (Table 2). Trees produced between 44 and $50 \mathrm{~kg}$ of fruit per tree irrespective of previous year's crop load and the level of flowering in the current year (Table 2). Thus, flower number was not the yield-limiting determinant and did not appear to affect bearing under conditions of this experiment. The effect of seededness on fruit growth potential was assessed following thinning the trees to 30 fruit to minimize interfruit competition for resources. The average weight of seeded fruit was $13 \%$ and $20 \%$ greater than seedless fruit on nonthinned and heavily-thinned 'Bartlett' pear trees, respectively (Table 2). The increases in fruit weight associated with fruit thinning were $56 \%$ and $66 \%$, respectively, in seedless and seeded fruit (Table 2). Seeded fruit contained an average of 7.7 seeds per fruit on heavilythinned trees (Table 3), which was very similar to seed number per fruit on nonthinned trees (Table 1).

Table 2. Effects of seeds and severity of fruit thinning in 1992 on fruit weight in 1992 and on return bloom (flowers clusters per tree), fruit per tree, yield and fruit weight in 1993 in 'Bartlett' pear. ${ }^{\text {' }}$ (Expt. 1.B. and Expt. 2).

\begin{tabular}{|c|c|c|c|c|c|c|}
\hline \multirow[b]{3}{*}{ Tree crop load } & \multirow{2}{*}{\multicolumn{2}{|c|}{$\begin{array}{c}1992 \\
\text { Fruit wt (g/fruit) }\end{array}$}} & \multicolumn{4}{|c|}{1993} \\
\hline & & & \multirow{2}{*}{$\begin{array}{l}\text { Flower clusters } \\
\text { per tree }\end{array}$} & \multirow{2}{*}{$\begin{array}{c}\text { Fruit no. } \\
\text { tree }\end{array}$} & \multirow{2}{*}{$\begin{array}{l}\text { Yield per } \\
\text { tree }(\mathrm{kg})\end{array}$} & \multirow{2}{*}{$\begin{array}{l}\text { Fruit wt } \\
(g / \text { fruit })^{y}\end{array}$} \\
\hline & Seedless & Seeded & & & & \\
\hline \multicolumn{7}{|c|}{ Nonthinned } \\
\hline$(\approx 270$ fruit/tree $)$ & 156 & $176(12.8)^{\mathrm{x}}$ & 275 & 269 & 47.5 & 177 \\
\hline \multicolumn{7}{|c|}{ Heavily thinned } \\
\hline$(\approx 30$ fruit/tree $)$ & $\begin{array}{l}244 \\
(56.4 \%)^{\mathrm{w}}\end{array}$ & $\begin{array}{r}292(19.7)^{\mathrm{x}} \\
(65.9 \%)^{\mathrm{w}}\end{array}$ & $396^{* *}$ & $269^{\text {Ns }}$ & $46.0^{\mathrm{Ns}}$ & 171 \\
\hline
\end{tabular}

${ }^{2}$ Means for eight trees per treatment.

${ }^{y}$ Yield per tree divided by fruit number per tree.

xPercentage increase in fruit size due to the "seed effect."

"Percentage increase in fruit size associated with greatly reduced interfruit competition.

ss, **NNonsignificant or significantly different from nonthinned at $P \leq 0.01$.

Seeded 'Bartlett' pears, like seeded 'Spencer Seedless' apples (Chan and Cain, 1967), inhibited return bloom. In contrast with the results of Chan and Cain (1967) and Huet (1972), however, seedless fruit also inhibited return bloom in both this study (Table 1) and a previous study in California (Griggs et al., 1970). Thus, seeds are apparently not the primary determinant of flowering in Californiagrown 'Bartlett' pear. Why Huet's studies, conducted in France, yielded different results than those in California is not apparent. The magnitude of the inhibitory effect of seeded fruit on flowering has been inconsistent among the various studies with both 'Spencer Seedless' apple and 'Bartlett' pear. Besides seed number, other endogenous, genotype-specific variables, such as length of bourse shoot and leaf area per spur, influence flowering (Chan and Cain, 1967; Dennis and Neilsen, 1999; Griggs et al., 1970; Huet, 1972; Neilsen, 1998; Neilsen and Dennis, 2000 ). Less frequently mentioned, however, are environmental variables of possible local or regional significance that influence the capacity for parthenocarpic fruit development in 'Bartlett' (Griggs and Iwakiri, 1954) or, perhaps, the inhibitory effect of seed development on flowering. Seeds were more inhibitory to 'Bartlett' flowering in France (Huet, 1972) than in California (Griggs et al., 1970). The magnitude of the inhibitory effect of seeded fruit on flowering was also inconsistent between studies with 'Spencer Seedless' apple (Chan and Cain, 1967; Neilsen, 1998; Neilsen and Dennis, 2000). The effect also varied annually as seed-associated inhibition of flowering in 'Spencer Seedless' varied between $30 \%$ and $90 \%$ within two trees (one
Table 3. The effects of pollination on fruit weight, fruit diameter and seed number per fruit under non-limiting resources (trees thinned to 30 fruit per tree), of 'Bartlett' pear in $1992 .^{\mathrm{z}}$

\begin{tabular}{lccc}
\hline Treatment & $\begin{array}{c}\text { Fruit wt } \\
\text { (g/fruit) }\end{array}$ & $\begin{array}{c}\text { Fruit diam } \\
(\mathrm{mm})\end{array}$ & $\begin{array}{c}\text { Seeds } \\
\text { per fruit }\end{array}$ \\
\hline Pollinated & $292^{\mathrm{z}}$ & 79.9 & 7.7 \\
Nonpollinated & $244^{* *}$ & $72.8^{* * *}$ & $0.0^{* *}$
\end{tabular}

${ }^{\mathrm{z}}$ Values represent means for four trees.

** Significantly different from pollinated at $P \leq 0.01$.

orchard) over a 7-year period (Neilsen, 1998; Neilsen and Dennis, 2000).

Biennial bearing has been linked to the inhibition of flower induction by seeded fruits in 'Spencer Seedless' apple (Chan and Cain, 1967; Dennis and Neilsen, 1999). In 'Bartlett' pear, however, flower number per tree was not a primary crop-limiting determinant in this experiment. Fruit yield was $\approx 47 \mathrm{~kg}$ per tree irrespective of the level of flowering (Table 2). Thus, as long as some minimal number of flowers was produced, additional flower production did not increase cropping. Previously published work on oaks (Quercus alba L., Sharp and Sprague, 1967) also suggests that crop is limited ultimately by the lack of carbohydrate resources (Lloyd, 1980), which may limit flower initiation (Jackson and Sweet, 1972; Monselise and Goldschmidt, 1982), promote abortion of flowers or immature fruit (Stephenson, 1981), and restrict fruit growth (Wright, 1989).

The presence of seeds increased the weight of 'Bartlett' pear fruit by $13 \%$ under natural crop loads and by $20 \%$ under reduced crop loads (Table 2). The increase in fruit size was probably not the result of an increase in photosynthetic capacity, since photosynthates should not have been limiting in heavily thinned trees. Thus, our data appear to indicate that seeds increase fruit sink strength. Increased resource availability on heavily thinned trees resulted in fruit growth increases of $56 \%$ and $65 \%$, in seedless and seeded fruit, respectively (Table 2). Thus, the "seed effect" on fruit growth, expressed as a percentage of fruit enlargement, increased as resource availability increased (Table 2).

\section{Conclusion}

Thirty years ago Chan and Cain (1967) conducted a simple, yet elegant, experiment that has been cited widely. The stimulatory effects of seeds on fruit growth were apparent in both 'Spencer Seedless' (Chan and Cain, 1967) and 'Bartlett' pear, (Tables 1 and 2), but the extent of the inhibition of return bloom attributable to seeds appears to differ greatly between the two genotypes. In different geographical locations and/or years, the magnitude of seed inhibition of flowering has varied within each of the two genotypes (Chan and Cain, 1967; Griggs et al., 1970; Huet, 1972; Neilsen, 1998; Neilsen and Dennis, 2000). Thus, seed-derived hormonal inhibitors may not function consistently as the primary determinant of floral inhibition in either 'Bartlett' pear or 'Spencer Seed- 
less'. The relative importance of nutritional factors, i.e., resource limitations and hormonal inhibitors, may be influenced both by genotype-specific and environmental variables, but one can not partition the relative importance of these variables in most apple cultivars, because parthenoocarpy is not characteristic of the species (Nyeki et al., 1998). In any case, broad extrapolation of Chan and Cain's results to other apple cultivars and other species may be inappropriate.

\section{Literature Cited}

Chan, B.G. and J.C. Cain. 1967. The effect of seed formation on subsequent flowering in apple. Proc. Amer. Soc. Hort. Sci. 91:63-68.

Dennis, F.G., Jr. and J.C. Neilsen. 1999. Physiological factors affecting biennial bearing in tree fruit: The role of seeds in apple. HortTechnology 9:317-322.

Griggs, W.H. and B.T. Iwakiri. 1954. Pollination and parthenocarpy in the production of 'Bartlett' pears in California. Hilgardia 22:643-678.

Griggs, W.H., G.C. Martin, and B.T. Iwakiri. 1970. The effect of seedless versus seeded fruit development on flower bud formation in pear. J. Amer. Soc. Hort. Sci. 95:243-248.

Grossman, Y.L. and T.M. DeJong. 1995. Maxi- mum fruit growth potential and seasonal patterns of resource dynamics during peach growth. Ann. Bot. 75:553-560.

Huet, J. 1972. Etude des effets des feuilles et des fruits sur l'induction florale des brachyblastes du poirier. Physiol. Veg. 10:529-545.

Jackson, D.I. and G.B. Sweet. 1972. Flower initiation in temperate woody plants. Hort. Abstr. 42:9-24.

Lloyd, D.G. 1980. Sexual strategies in plants I. An hypothesis of serial adjustment of material investment during one reproductive session. New Phytol. 86:69-79.

McArtney, S.J. 1994. Exogenous gibberellin affects biennial bearing and the fruit shape of 'Braeburn' apple. N.Z. J. Crop and Hort. Sci. 22:343-346.

Monselise, S.P. and E.E. Goldschmidt. 1982. Alternate bearing in fruit trees. Hort. Rev. 4:128-173.

Neilsen, J.C. 1998. Endogenous control of flowering in apple. PhD Diss., Dept. of Horticulture, Michigan State Univ., East Lansing.

Neilsen, J.C. and F.G. Dennis, Jr. 2000. Effects of seed numbers, fruit removal, bourse shoot length and crop density on flowering in 'Spencer Seedless' apple. Acta Hort. 527:137-146.

Newell, E.A. 1991. Direct and delayed costs of reproduction in Aesculus californica. J. Ecol. 79:365-378.

Nyeki, J., M. Soltesz, and J. Ivancsics. 1998. Natu- ral tendency to parthenocarpy of pear varieties in Hungary. Acta Hort. 475:367-377.

Proctor, J.T.A. 1989. Bock G. Chan and J.C. Cain. 1967. The effect of seed formation on subsequent flowering in apple. Proc. Amer. Soc. Hort. Sci. 91:63-68 p. 383-391. In J. Janick. (ed.) Classic papers in horticultural science. Prentice Hall, Englewood Cliffs, N.J.

Sharp, W.M. and V.G. Sprague. 1967. Flowering and fruiting in the white oaks. Pistillate flowering, acorn development, weather and yields. Ecology 48:243-251.

Sprugel, D.G., T.M. Hinkley, and W. Schaap. 1991. The theory and practice of branch autonomy. Annu. Rev. Ecol. Syst. 22:309-334.

Stanton, M.L., J.K. Bereczky, and H.D. Hasbrouck. 1987. Pollination thoroughness and material yield regulation in wild radish, Raphanus raphanistrum. Oecologia 74:68-76.

Steffens, G.J., A.E. Stafford, and J.T. Lin. 1991. Influence of an inhibitor of gibberellin biosynthesis, paclobutrazol, on apple seed gibberellin content. Physiol. Plant. 83:366-372.

Stephenson, A.G. 1981. Flower and fruit abortion: Proximate causes and ultimate functions. Annu. Rev. Ecol. Syst. 12:253-279.

Wright, C.J. 1989. Interactions between vegetative and reproductive growth, p. 15-27. In: C.J. Wright (ed.). Manipulation of fruiting. Butterworths, London. 